\title{
Toxoplasma gondii infection affects cognitive function - corrigendum
}

\author{
Jaroslav Flegr ${ }^{1}$, Wojciech Guenter ${ }^{2}$, Maciej Bieliński ${ }^{2,4}$, Aleksander Deptula ${ }^{3}$, Patrycja Zalas-Więcek ${ }^{3}$, \\ Malgorzata Piskunowicz ${ }^{2}$, Krzysztof Szwed ${ }^{2}$, Adam Buciński ${ }^{5}$, Eugenia Gospodarek ${ }^{3}$ and Alina Borkowska ${ }^{2}$
}

\author{
${ }^{1}$ Departments of Biology, Faculty of Science, Charles University, Viničná 7, Prague 2, Czech Republic; \\ ${ }^{2}$ Chair and Department of Clinical Neuropsychology, Nicolaus Copernicus University, Collegium Medicum, M. Skłodowskiej- \\ Curie 9, 85-094 Bydgoszcz, Poland; \\ ${ }^{3}$ Chair and Department of Microbiology, Nicolaus Copernicus University, Collegium Medicum, M. Skłodowskiej-Curie 9, 85-094 \\ Bydgoszcz, Poland; \\ ${ }^{4}$ Division of Vascular Diseases and Internal Medicine, Dr Jan Biziel University Hospital No. 2, Ujejskiego 75, 85-168 Bydgoszcz, \\ Poland; \\ ${ }^{5}$ Department of Biopharmacy, Nicolaus Copernicus University, Collegium Medicum, A. Jurasza 2, 85-089 Bydgoszcz, Poland
}

In the recent issue of Folia Parasitologica (59: 93-98), Guenter et al. (2012) published results of a study showing that the effect of latent toxoplasmosis on cognitive function of 70 subjects cannot be proved to exist using a panel of five neuropsychological tests (Guenter et al. 2012). It must be mentioned that the data (mostly ordinal variables without normal distribution) were analysed either with parametric tests (GLM) or with more proper nonparametric tests, but without controlling for age and sex of subjects. It is known for a long time that shifts in personality profile and behaviour associated with latent toxoplasmosis differ very often in their direction between men and women (Flegr and Hrdý 1994, Flegr et al. 1996; Lindová et al. 2006, 2010). This raises the question whether cognitive functions reveal a similar phenomenon.

Therefore, we re-analysed the data on 56 women and 14 men separately. To control for the effect of age, which is known to influence the performance of subjects and also the probability of being Toxoplasma-infected, we analyzed the data with partial Kendall regression, the nonparametric technique that controls for one confounding variable (Kaňková et al. 2011). The results showed that, generally, women scored worse in tests except Digit span-backward test (significantly worse only in the verbal fluency test, $p=0.015$ ), whereas males scored better in all tests except in percentage of correct answers in N-back test (significantly better in digit span-forward, $p=0.008$ and in Stroop test I, $\mathrm{p}=0.017$ ).

Published results of a simple reaction time test show that psychomotor performance of both men and women is lower in subjects with latent toxoplasmosis (Flegr et al. 2008). However, most of personality factors and in some population also intelligence are shifted in an opposite direction in Toxoplasma-infected men and women

Table 1. Effect of latent toxoplasmosis on cognitive functions. Table shows means for Toxplasma-free (Toxo-) and Toxoplasma-infected (Toxo ${ }^{+}$) women and men, and effect size (Tau) and significance (p) of the effect of toxoplasmosis on performance in particular tests estimated with partial Kendall correlation tests. The significant $\mathrm{p}$ are printed in bold. Positive Tau for TMT A and B, Stroop test I and II, and N-back test reaction time (everything measured in seconds) indicate worse cognitive function in Toxoplasma-infected subjects, negative Tau for these tests means better cognitive function for Toxoplasma-infected subjects. The opposite is true for other tests.

\begin{tabular}{|c|c|c|c|c|c|c|c|c|}
\hline & \multicolumn{4}{|c|}{ women } & \multicolumn{4}{|c|}{ men } \\
\hline & $\begin{array}{l}\text { mean } \\
\text { Toxo- }\end{array}$ & $\begin{array}{l}\text { mean } \\
\text { Toxo+ }\end{array}$ & Tau & $\mathrm{p}$ & $\begin{array}{l}\text { mean } \\
\text { Toxo- }\end{array}$ & $\begin{array}{l}\text { mean } \\
\text { Toxo }^{+}\end{array}$ & Tau & $\mathrm{p}$ \\
\hline TMT A (sec.) & 19.639 & 20.850 & 0.041 & 0.656 & 23.000 & 19.833 & -0.329 & 0.102 \\
\hline TMT B (sec.) & 45.583 & 52.750 & 0.078 & 0.398 & 44.500 & 45.667 & -0.201 & 0.317 \\
\hline Stroop Test I (sec.) & 19.194 & 20.100 & 0.054 & 0.560 & 19.500 & 17.167 & -0.478 & 0.017 \\
\hline Stroop Test II (sec.) & 46.417 & 49.000 & 0.009 & 0.918 & 43.625 & 43.333 & -0.166 & 0.408 \\
\hline Verbal Fluency Test & 44.917 & 39.700 & -0.224 & 0.015 & 46.500 & 41.833 & 0.190 & 0.343 \\
\hline Digit Span forwards & 6.500 & 6.050 & -0.101 & 0.273 & 6.750 & 9.500 & 0.532 & 0.008 \\
\hline Digit Span backwards & 6.750 & 6.600 & 0.085 & 0.354 & 9.125 & 8.500 & 0.112 & 0.577 \\
\hline N-back Test $-\%$ correct answers & 90.667 & 82.400 & -0.126 & 0.171 & 95.500 & 87.000 & -0.250 & 0.213 \\
\hline N-back Test - reaction time (sec.) & 607.694 & 743.200 & 0.068 & 0.458 & 546.500 & 450.167 & -0.302 & 0.132 \\
\hline
\end{tabular}

Address for correspondence: J. Flegr, Faculty of Science, Charles University, Viničná 7, CZ-128 44 Praha 2, Czech Republic. Phone: +420 221951821; Fax: +420 224919704; E-mail: flegr@cesnet.cz 
(Flegr and Havlíček 1999). The results in most cognitive tests are influenced not only by cognitive performance of a subject but also by his/her motivation. We speculate that the differences in shift of personality profile, for example those related to increased motivation of testosterone-high Toxoplasma-infected male subjects (Flegr et al. 2008), can explain the present data that show better performance of Toxoplasma-infected men in several cognitive tests.

\section{REFERENCES}

Flegr J., HavlíčeK J. 1999: Changes in the personality profile of young women with latent toxoplasmosis. Folia Parasitol. 46: $22-28$.

Flegr J., HRdý I. 1994: Influence of chronic toxoplasmosis on some human personality factors. Folia Parasitol. 41: 122-126.

Flegr J., Novotná M., Lindová J., Havlíček J. 2008: Neurophysiological effect of the $\mathrm{Rh}$ factor. Protective role of the $\mathrm{RhD}$ molecule against Toxoplasma-induced impairment of reaction times in women. Neuroendocrinol. Lett. 29: 475-481.

Flegr J., Zitková Š., Kodym P., Frynta D. 1996: Induction of changes in human behaviour by the parasitic protozoan Toxoplasma gondii. Parasitology 113: 49-54.

Guenter W., Bielinski M., Deptula A., Zalas-Wiecek P., Piskunowicz M., Szwed K., Bucinski A., Gospodarek E., BorkowsKa A. 2012: Does Toxoplasma gondii infection affect

Received 12 October 2012 cognitive function? A case control study. Folia Parasitol. 59: 93-98.

KañKová Š., Kodym P., Flegr J. 2011: Direct evidence of Toxoplasma-induced changes in serum testosterone in mice. Exp. Parasitol. 128: 181-183.

Lindová J., KubĚna A.A., Šturcová H., KŘivohlavá R., NovotnÁ M., Rubešová A., Havlíšek J., Kodym P., Flegr J. 2010: Pattern of money allocation in experimental games supports the stress hypothesis of gender differences in Toxoplasma gondii-induced behavioural changes. Folia Parasitol. 57: 136-142.

Lindová J., Novotná M., Havlíček J., Jozífková E., Skallová A., Kolbeková P., Hodný Z., Kodym P., Flegr J. 2006: Gender differences in behavioural changes induced by latent toxoplasmosis. Int. J. Parasitol. 36: 1485-1492. 